Journal of Southeast Asian

2011

\title{
The p0wer of numbers
}

Sumeia Williams

msumeia@gmail.com

Follow this and additional works at: https://docs.lib.purdue.edu/jsaaea

\section{Recommended Citation}

Williams, Sumeia (2011) "The p0wer of numbers," Journal of Southeast Asian American Education and Advancement: Vol. 6 : Iss. 1, Article 23.

DOI: $10.7771 / 2153-8999.1039$

Available at: https://docs.lib.purdue.edu/jsaaea/vol6/iss1/23

This document has been made available through Purdue e-Pubs, a service of the Purdue University Libraries. Please contact epubs@purdue.edu for additional information.

This is an Open Access journal. This means that it uses a funding model that does not charge readers or their institutions for access. Readers may freely read, download, copy, distribute, print, search, or link to the full texts of articles. This journal is covered under the CC BY-NC-ND license. 
Williams: The power of numbers

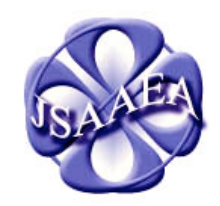

Volume 6 (2011)

\section{Journal of Southeast Asian American Education \& Advancement}

WWw.JSAAEA.org
A peer-reviewed

scholarly journal published by the National Association for the Education \& Advancement of Cambodian, Laotian, and Vietnamese Americans (NAFEA)

\title{
The p0wer of numbers
}

\author{
by \\ Sumeia Williams
}

Decades passed before I could grasp

the concept beyond

the lifting of (over) 3000 children

plus the deaths of some 58000 Americans

equals

a pledge of allegiance to one nation

under God, indivisible

It only took 2 angry fathers (minus 2 sons)

plus 1 word (gook) ${ }^{10}$

to bury 20 years of America's

military involvement in Vietnam

\footnotetext{
(c)

SOMERIGHISRESERED Readers are free to copy, display, and distribute this article, as long as the work is attributed to the author(s) and the Journal of Southeast Asian American Education \& Advancement, it is distributed for noncommercial purposes only, and no alteration or transformation is made in the work. More details of this Creative Commons license are available at http://creativecommons.org/licenses/by-nc-nd/3.0/. All other uses must be approved by the author(s) or JSAAEA.
} 
beneath my skin

and throw the whole thing

out

of

balance

\begin{abstract}
About the Author

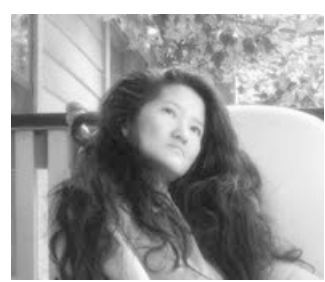

Sumeia Williams was born in Saigon, Vietnam in 1970. Formerly Le Thi Buu Tran, she was adopted and brought to the US as an infant. Inspired by a handful of unapologetic, brutally honest members of the Korean adoptee community, she began documenting her experiences as a Vietnamese adoptee and Asian American woman on a blog named "Ethnically Incorrect Daughter" (http://ethnicallyincorrect.wordpress.com/). She currently lives in Texas where she continues her career as a mom, sporadic writer, artist and advocate for adoptee rights. Her work has appeared both online and in print in publications such as The New York Times, Nha Magazine, Pacific Citizen, Adoption Australia and Tuổi Trẻ.
\end{abstract}




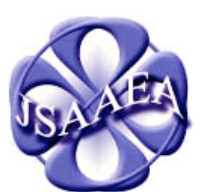

Volume 6 (2011)

\section{Journal of Southeast Asian American Education \& Advancement}

WWW.JSAAEA.org

\section{Editor}

Dr. Wayne E. Wright

University of Texas, San Antonio

Associate Editors

Dr. Chhany Sak-Humphry

University of Hawaii

Dr. KimOanh Nguyen-Lam

California State University, Long Beach

Book Review Editor

Dr. Vichet Chhuon

University of Minnesota

\section{Creative Works Editor}

Bryan Thao Worra

Lao Assistance Center

Special Advisor

Gregory Green

Curator, Echols Collection on Southeast Asia, Cornell University Library

Journal Manager

Sovicheth Boun

University of Texas, San Antonio
A peer-reviewed

scholarly journal published by the

National Association

for the Education \&

Advancement of

Cambodian, Laotian,

and Vietnamese

Americans (NAFEA)

Comments and questions for the editorial staff may be directed to jsaaea@1ists.sis.utsa.edu

\section{Editorial Review Board}

\author{
Dr. Steve Arounsack \\ California State University, Stanislaus \\ Dr. Phala Chea \\ Lowell Public Schools \\ Dr. Loan Dao \\ Cancer Prevention Institute of California \\ Dr. Sophal Ear \\ U.S. Naval Postgraduate School \\ Dr. Nancy H. Hornberger \\ University of Pennsylvania \\ Dr. Peter Nien-Chu Kiang \\ University of Massachusetts, Boston
}

Dr. Carl L. Bankston III

Tulane University

Dr. George Chigas

University of Massachusetts, Lowell

Dr. Changming Duan

University of Missouri, Kansas City

Dr. Jeremy Hein

University of Wisconsin - Eau Claire

Dr. Samlong Inthaly

Minneapolis Public Schools

Dr. Kevin K. Kumashiro

University of Illinois, Chicago 


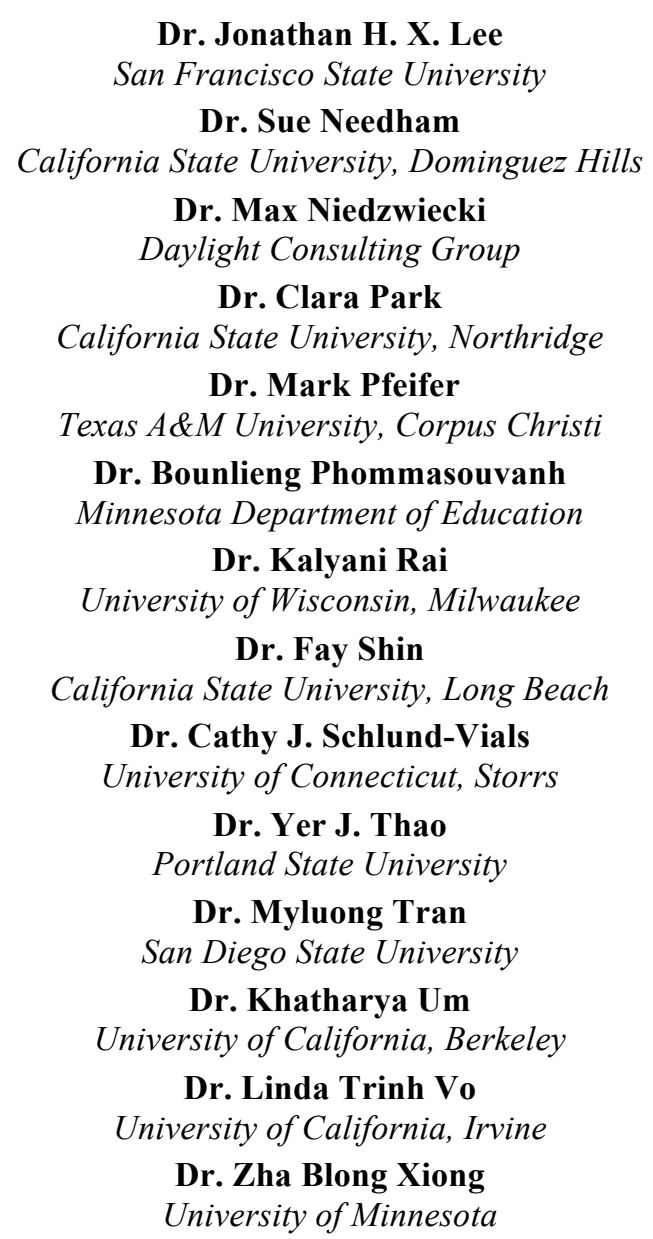

\author{
Dr. Stacey Lee \\ University of Wisconsin, Madison \\ Dr. Bic Ngo \\ University of Minnesota \\ Dr. Leakhena Nou \\ California State University, Long Beach \\ Dr. Isabelle Thuy Pelaud \\ San Francisco State University \\ Dr. Loan T. Phan \\ University of New Hampshire \\ Dr. Karen Quintiliani \\ California State University, Long Beach \\ Dr. Angela Reyes \\ Hunter College, The City University of New York \\ Dr. Nancy J. Smith-Hefner \\ Boston University \\ Dr. Christine Su \\ Ohio University \\ Dr. Loan Tran \\ University of California, Riverside \\ Dr. Tinou Tran \\ Alief Independent School District \\ Dr. Phitsamay Sychitkokhong Uy \\ University of Massachusetts, Lowell \\ Dr. Terrence G. Wiley \\ Center for Applied Linguistics \\ Dr. Kou Yang \\ California State University, Stanislaus
}

\section{Doctoral Student Editorial Review Board}

\author{
Keo Chea-Young \\ University of Pennsylvania \\ Ketmani Kouanchao \\ California State University, Fullerton \\ Polinda Keo \\ University at Albany \\ Ravy Lao \\ University of California, Santa Barbara \\ Thien-Huong Ninh \\ University of Southern California \\ Malaphone Phommasa \\ University of California, Santa Barbara \\ Rassamichanh Souryasack \\ University of California, Santa Barbara \\ Alisia Tran \\ University of Minnesota \\ Silvy Un \\ University of Minnesota
}

\author{
Annie BichLoan Duong \\ San Joaquin County Office of Education \\ Peter Tan Keo \\ Columbia University \\ Ha Lam \\ Arizona State University \\ Monirith Ly \\ Texas State University-San Marcos \\ Giang Pham \\ University of Minnesota \\ Vanna Som \\ Harvard University \\ Somongkol Teng \\ University of Minnesota \\ Krissyvan Truong \\ Claremount Graduate University \\ Yang Sao Xiong \\ University of California, Los Angeles
}

